\title{
Performance and Metabolism of Dairy Cows Fed Bean Seeds (Vicia faba) with Different Levels of Anti-Nutritional Substances
}

\author{
Veronika Melicharová, Alena Pechová, Rudolf Dvořák, Leoš Pavlata \\ Clinic of Ruminant Diseases, Faculty of Veterinary Medicine, University of Veterinary and Pharmaceutical \\ Sciences Brno, Czech Republic
}

Received May 22, 2008

Accepted December 15, 2008

\begin{abstract}
The aim of this study was to determine the effect of selected bean cultivars with different levels of anti-nutritional substances on performance and metabolism of dairy cows. In the current twelve-week-long study, 32 dairy cows at 3 to 6 weeks after parturition were divided into four groups. Diets were balanced to have an analogical content of crude protein and energy. Experimental groups (MI, ME, MET) were mixed to the milking concentrate consisting of $20 \%$ bean seeds (MI - MISTRAL cultivar with a low content of anti-nutritional substances; ME - MERKUR cultivar with high content of anti-nutritional substances; MET MERKUR cultivar with technologically reduced the amount of anti-nutritional substances). Clinical evaluation of dairy cows' health and feed intake showed no negative effect of the bean supplementations. Energy, nitrogen and mineral metabolisms were not impaired either. No significant differences were found between groups in milk performance (daily milk yield, protein and lactose production) during the study.

On the basis of these results, the bean can be used in $20 \%$ in the milking concentrate of dairy cattle. Health risks associated with anti-nutritional content of the native bean are not significant for high-producing dairy cattle.
\end{abstract}

Bean, metabolism, milk performance, reproduction, anti-nutritional substances

Bean seeds (Faba vulgaris Moench., syn. Vicia faba L.) are important sources of proteins used in diets of farm animals. Globally, the bean and lupin are grown on the smallest acreage among all pulses. In our climate, beans are used mainly as a fodder crop. Bean seeds contain on average $30-34 \%$ crude protein (CP), 6-7\% fibre, $47-51 \% \mathrm{~N}$-free extract (NFE), 33$40 \%$ starch, $0.9 \%$ ether extract (EE), and 3.3-3.7\% ash. When compared to soybean, bean has lower lysine and arginine values (17.6 g. $\mathrm{kg}^{-1} \mathrm{vs} .25 .5 \mathrm{~g} \cdot \mathrm{kg}^{-1}$, respectively) and a low content of sulphur amino acids $\left(6 \mathrm{~g} \cdot \mathrm{kg}^{-1}\right.$ vs. $13.3 \mathrm{~g} \cdot \mathrm{kg}^{-1}$ of feed ration's dry matter) (Cerioli et al. 1998). Protein and starch degradability of the bean can be influenced by technological treatment. Aleksić et al. (1999a) tested the protein degradability of faba beans in the rumen of cannulated lactating cows. The rate of protein degradability was determined as more than 47\%. Aguilera et al. (1992) reported lower degradability of protein by heat treatment $\left(120^{\circ} \mathrm{C}\right.$ for $\left.30 \mathrm{~min}\right)$ of bean compared to untreated bean. Benchaar et al. (1992) studied the effect of extruded bean, representing $45 \%$ of the feeding ration protein content, on digestion of nitrogenous substances and starch in the rumen and small intestine. The percentage of degradable protein in the intestine was $38 \%$ in extruded bean as compared with $33.5 \%$ in untreated bean. Cros et al. (1991) came to a similar conclusion and they found that adding extruded bean seeds to diet increases intestinal availability of proteins from the feed. The effect of bean heat treatment on amino acid composition was studied by Cros et al. (1992). Dairy cows fed heat-treated beans showed better utilization of amino acids in the small intestine. Extrusion did not affect amino acids composition. Similarly Yu et al. (2000) stated that extrusion of bean at $136^{\circ} \mathrm{C}$ for $15 \mathrm{~min}$ yielded the highest values of actually digestible protein in the intestine and, at the same time, it maintained a sufficient amount of degradable protein for microbial proteosynthesis. Martinez et al. (2004) describe better utilization of protein in ruminants fed protein concentrates (bean meal) with

Address for correspondence:

Doc. MVDr. Alena Pechová, CSc., Dipl. ECBHM

Ruminant clinic, Faculty of Veterinary Medicine,

University of Veterinary and Pharmaceutical Sciences Brno,

Palackého 1-3, 61242 Brno, Czech Republic

Phone: +420 541562408

E-mail: pechovaa@vfu.cz

http://www.vfu.cz/acta-vet/actavet.htm 
tannins added. The rumen hydrolysis and deamination of protein was significantly lower in cows fed protein concentrates with tannins. The protein utilization was enhanced and no change in starch digestion after treatment of tannins was found.

The effective starch degradability of faba bean grains in the rumen of lactating cows was determined to be more than 58\% (Aleksic et al. 1999b). Benchaar et al. (1992) studied the effect of heat treatment of bean (extrusion) on the utilization of starches in the small intestine of dairy cows. Feeding extruded beans improved ruminal digestibility of starches compared to untreated beans ( $72 \%$ vs. $58 \%)$ and their subsequent utilization in the small intestine ( 0.98 vs. $\left.1.61 \mathrm{~kg} \cdot \mathrm{day}^{-1}\right)$. Other authors reported a decrease in starch digestibility in the rumen after feeding extruded beans, though it increased again when feeding a mixture of various pulses (Goelema et al. 1998).

The anti-nutritional substances present in the bean can negatively influence the digestion of individual nutrient and also the health state and performance of the high-producing dairy cows. The bean contains the following anti-nutritional substances: trypsin inhibitors, lectins (phytohaemaglutinins), tannins, flatulent oligosaccharides, gallic acid and other substances from the phenolic group, and glycosides such as vicine and convicine (Dvořák et al. 2006). The bean has a lower content of trypsin inhibitors than the soybean $\left(0.97 \mathrm{mg} \cdot \mathrm{g}^{-1}\right.$ vs. $18 \mathrm{mg} \cdot \mathrm{g}^{-1}$ respectively), shows no urease activity, which reaches $2.9 \mathrm{mg} \mathrm{N} \cdot \mathrm{g}^{-1}$ in the soybean, but contains more tannins $\left(3.1 \mathrm{mg} \cdot \mathrm{kg}^{-1} \mathrm{vs} .0 \mathrm{mg} \cdot \mathrm{kg}^{-1}\right)($ Cerioli et al. 1998).

The aim of our experiment was to evaluate the influence of the content of anti-nutritional substances in the bean on the metabolism and performance of the high producing dairy cows. We used two different bean cultivars: Mistral with a low and Merkur with a high content of antinutritional substances. We also tested the Merkur cultivar whose content of antinutritional substances was reduced technologically using a new method of technological treatment developed for this reason.

\section{Materials and Methods}

The experiment was performed in a four-row tie-up barn (located in eastern Bohemia) in 2006. Thirty-two dairy cows were used in the study. They were at the beginning of their lactation period, i.e. 3 to 6 weeks after parturition. They were divided into 3 experimental groups and 1 control group on the principle of analogous tetrads according to breed, order of lactation, performance in the last lactation and the current performance. All dairy cows were fed the same basic diet (Table 1) supplemented with milking concentrate. The experimental groups were fed a milking concentrate containing $20 \%$ of bean seeds. Group MI was fed the Mistral cultivar with a low anti-nutritional content; the Merkur cultivar with high anti-nutritional content was fed to group $\mathrm{ME}$; and group MET was fed the Merkur cultivar whose content of anti-nutritional substances was reduced technologically. This technology based on patent No. 285745 was further modified by adjusting the reactor temperature, the duration of exposure to that temperature and the duration of ageing of the material thus treated. The control group was fed the milking concentrate with a higher proportion of extracted soybean meal and grain meal. The dairy cows were fed the experimental diet for 12 weeks. The composition of milking concentrate for the control and experimental groups is detailed in Table 2. All milking concentrates had an analogical content of nutrients (Table 3). The levels of anti-nutritional substances in individual bean cultivars are detailed in Table 4.

Feeding procedures were similar for

Table 1. Composition of basic diet for control and experimental groups at an expected average milk yield of 301

\begin{tabular}{|l|c|c|}
\hline \multicolumn{1}{|c|}{ Feed } & & Cow/day \\
\hline Meadow hay & $\mathrm{kg}$ & 0.85 \\
\hline Maize silage & $\mathrm{kg}$ & 13.01 \\
\hline Clover silage & $\mathrm{kg}$ & 17.19 \\
\hline CCM & $\mathrm{kg}$ & 0.93 \\
\hline Beet pulp dried & $\mathrm{kg}$ & 1.86 \\
\hline Production mixture & $\mathrm{kg}$ & 8.00 \\
\hline Mineral supplements & $\mathrm{kg}$ & 0.10 \\
\hline
\end{tabular}
all groups. Milking concentrates were supplied to troughs according to the level of expected milk yield, starting with milk yield guaranteed by basic diet (101) in a ration of $400 \mathrm{~g}$ per one 1 of milk. Single ration never exceeded $2 \mathrm{~kg}$. The expected milk yield of 301 was then ensured by $8 \mathrm{~kg}$ of milking concentrate. Changes to the milking concentrate were done gradually in the course of 5 days.

The metabolism of dairy cows was examined via regular blood, urine and rumen fluid sampling. The first samples 
Table 2. Composition of milking concentrate for control and experimental groups (MI: Mistral, ME: Merkur, MET: Merkur-treated, C: Control)

\begin{tabular}{|l|c|c|c|c|}
\hline \multicolumn{1}{|c|}{ Feed } & MI (\%) & ME $(\%)$ & MET (\%) & C (\%) \\
\hline Wheat & 22.0 & 22.0 & 22.0 & 22.0 \\
\hline Barley & 6.5 & 5.0 & 5.0 & 10.0 \\
\hline Oat & 5.0 & 5.0 & 5.0 & 5.0 \\
\hline Triticale & 16.0 & 15.0 & 15.0 & 9.0 \\
\hline Flax & 1.0 & 1.0 & 1.0 & 1.0 \\
\hline Extracted soybean meal (48\%) & 12.0 & 14.0 & 14.0 & 19.0 \\
\hline Rape-cake (30\%) & 10.0 & 10.5 & 10.5 & 11.0 \\
\hline Megalac* & 2.5 & 2.5 & 2.5 & --- \\
\hline Feeding limestone & 1.0 & 1.0 & 1.0 & 1.0 \\
\hline Acid sodium carbonate & 1.0 & 1.0 & 1.0 & 1.0 \\
\hline Mineral supplements & 3.0 & 3.0 & 3.0 & 3.0 \\
\hline Bean meal - Merkur & --- & 20.0 & --- & -- \\
\hline Bean meal - Merkur treated & --- & --- & 20.0 & -- \\
\hline Bean meal - Mistral & 20.0 & --- & -- & - \\
\hline Maize & --- & --- & 18.0 \\
\hline
\end{tabular}

*Calcium salt of palm oil oleic acid (ME $30 \mathrm{MJ} / \mathrm{kg}$ )

Table 3. Nutrient content of diets for control and experimental groups at an expected average milk yield of 301 (MI: Mistral, ME: Merkur, MET: Merkur treated, C: Control)

\begin{tabular}{|l|r|r|r|r|r|}
\hline & & \multicolumn{1}{|c|}{ MI } & \multicolumn{1}{c|}{ ME } & \multicolumn{1}{c|}{ MET } & \multicolumn{1}{c|}{ C } \\
\hline Dry matter & $\mathrm{kg}$ & 20250 & 20150 & 20200 & 20400 \\
\hline Crude protein & $\mathrm{g}$ & 3250 & 3250 & 3250 & 3260 \\
\hline Ether extract & $\mathrm{g}$ & 919 & 922 & 916 & 808 \\
\hline Crude fibre & $\mathrm{g}$ & 3156 & 3157 & 3128 & 3088 \\
\hline $\mathrm{NEL}$ & $\mathrm{MJ}$ & 130 & 129 & 129 & 131 \\
\hline $\mathrm{Ca}$ & $\mathrm{g}$ & 192 & 199 & 247 & 175 \\
\hline $\mathrm{P}$ & $\mathrm{g}$ & 90 & 87 & 88 & 88 \\
\hline $\mathrm{Mg}$ & $\mathrm{g}$ & 64 & 64 & 64 & 65 \\
\hline
\end{tabular}

were taken at the beginning of the experiment. Further samples were taken at four-week intervals, i.e. at the end of the first, second and third month of the experiment. Blood was taken in Hemos sampling kits that were free of any anti-coagulant in order to obtain blood serum. Rumen fluid was collected orally using a rumen probe and suction. Samples were preserved in toluene in order to determine volatile fatty acids, by formaldehyde to determine infusoria, and by mercuric chloride for other indicators.

The following indicators of blood serum were determined: total protein (TP), urea, total bilirubin, $\gamma$-glutamyltransferase (GMT), total cholesterol, non-esterified fatty acids (NEFA), $\beta$-hydroxybutyrate (BHB), calcium (Ca), phosphorus (P), magnesium (Mg). Rumen fluid was tested for $\mathrm{pH}$, total acidity (TA), infusoria counts, ammonia, lactic acid, volatile fatty acids (VFA), propionic acid, acetic acid, butyric acid and valeric acid.

The majority of biochemical indicators were determined by photometric methods using an automatic analyzer Cobas Mira. The methods are sorted by manufacturers of the tests:

- LACHEMA - urea (Urea UV KIN 4 × 50, Cat. No. 1307017), total bilirubin (BIL 100, Cat. No. 1105309), GMT (GMT KIN 100, Cat. No. 1302082)

- BioVendor - total protein ( ${ }^{\mathrm{L} P r o t e i n}$ total, Cat. No. 12751), total cholesterol ( ${ }^{\mathrm{L} C h o l e s t e r o l, ~ C a t . ~ N o .10851) ~}$

- RANDOX - non-esterified fatty acids (NEFA, Cat. No. FA 115), $\beta$ - hydroxybutyrate (RANBUT, Cat. No, RB 1008).

Minerals $(\mathrm{Ca}, \mathrm{Mg})$ were determined by flame atomic absorption spectrophotometry using AAS Solaar M6 appliance.

The indicators of rumen profile were identified by the following methods: total acidity - $0.1 \mathrm{M} \mathrm{NaOH}$ titration; ammonia - Berthelot reaction (Broderick et al. 1980); infusoria counts - microscopically, after staining with methylene blue; VFA - gas chromatography; and lactic acid - enzymatically. 
Table 4. Contents of anti-nutritional substances in individual bean cultivars used in diets ((MI: Mistral, ME: Merkur, MET: Merkur-treated)

\begin{tabular}{|lc|c|c|c|}
\hline & & \multicolumn{1}{c|}{ MI } & \multicolumn{1}{c|}{ ME } & \multicolumn{1}{c|}{ MET } \\
\hline Trypsin inhibitors & $(\mathrm{TIU})$ & $6.04 \pm 0.23$ & $6.44 \pm 0.26$ & $0.77 \pm 0.16$ \\
\hline Tannins & $\left(\mathrm{mg} \cdot \mathrm{kg}^{-1}\right)$ & $40.92 \pm 1.85$ & $62.78 \pm 4.54$ & $20.92 \pm 2.15$ \\
\hline Lectins & $(\mathrm{titre})$ & $30.67 \pm 23.74$ & $29.33 \pm 5.96$ & $34.67 \pm 14.36$ \\
\hline Raffinose & $\left(\mathrm{g} \cdot \mathrm{kg}^{-1}\right)$ & $0.11 \pm 0.00$ & $1.14 \pm 0.04$ & $0.97 \pm 0.07$ \\
\hline Stachyose & $\left(\mathrm{g} \cdot \mathrm{kg}^{-1}\right)$ & $5.70 \pm 0.11$ & $5.67 \pm 0.17$ & $3.78 \pm 0.15$ \\
\hline Verbascose & $\left(\mathrm{g} \cdot \mathrm{kg}^{-1}\right)$ & $14.96 \pm 0.24$ & $15.19 \pm 0.22$ & $9.26 \pm 0.62$ \\
\hline p-cumaruic acid & $\left(\mathrm{mg} \cdot \mathrm{kg}^{-1}\right)$ & $8.73 \pm 5.54$ & $9.16 \pm 8.28$ & $5.69 \pm 2.82$ \\
\hline Ferulic acid & $\left(\mathrm{mg} \cdot \mathrm{kg}^{-1}\right)$ & $11.26 \pm 2.46$ & $10.08 \pm 1.14$ & $6.99 \pm 1.32$ \\
\hline Gallic acid & $\left(\mathrm{mg} \cdot \mathrm{kg}^{-1}\right)$ & $0.00 \pm 0.00$ & $3.45 \pm 4.89$ & $0.00 \pm 0.00$ \\
\hline Protocatechuic acid & $\left(\mathrm{mg} \cdot \mathrm{kg}^{-1}\right)$ & $14.04 \pm 4.07$ & $17.43 \pm 6.54$ & $22.94 \pm 5.71$ \\
\hline 3,4- dihydroxybenzaldehyde & $\left(\mathrm{mg} \cdot \mathrm{kg}^{-1}\right)$ & $8.66 \pm 3.64$ & $12.94 \pm 4.27$ & $25.74 \pm 4.35$ \\
\hline p-hydroxybenzoic acid & $\left(\mathrm{mg} \cdot \mathrm{kg}^{-1}\right)$ & $21.96 \pm 8.64$ & $16.58 \pm 3.27$ & $25.39 \pm 10.36$ \\
\hline p-hydroxybenzaldehyde & $\left(\mathrm{mg} \cdot \mathrm{kg}^{-1}\right)$ & $2.31 \pm 0.72$ & $2.07 \pm 0.82$ & $4.60 \pm 1.20$ \\
\hline Vanillic acid & $\left(\mathrm{mg} \cdot \mathrm{kg}^{-1}\right)$ & $12.84 \pm 8.95$ & $8.81 \pm 2.80$ & $10.79 \pm 0.78$ \\
\hline Caffeic acid & $\left(\mathrm{mg} \cdot \mathrm{kg}^{-1}\right)$ & $18.57 \pm 6.15$ & $19.07 \pm 3.65$ & $18.65 \pm 6.99$ \\
\hline Vicine & $\left(\mathrm{mg} \cdot \mathrm{g}^{-1}\right)$ & $7.77 \pm 0.78$ & $8.65 \pm 0.28$ & $8.62 \pm 0.90$ \\
\hline Convicine & $\left(\mathrm{mg} \cdot \mathrm{g}^{-1}\right)$ & $4.58 \pm 0.82$ & $2.77 \pm 0.31$ & $4.00 \pm 1.02$ \\
\hline
\end{tabular}

The health state of the cows was continually monitored by keepers and the local veterinary surgeon. The evaluation of daily milk production was realized monthly.

The results were statistically evaluated using F-test to evaluate variations in individual files and, depending on the result, by Student's $t$-test for samples with equal/unequal variations. The evaluation was performed using MS-Excel ${ }^{\circledR}$ software (Microsoft Corp., Inc.).

\section{Results and Discussion}

Evaluation of the state of health and metabolism of dairy cows

Clinical evaluation of the health status of dairy cows showed no differences among the individual groups. Also milking concentrates with a higher content of the bean were accepted well by dairy cows and no differences were found between individual cultivars. Brunschwig and Lamy (2003) reported even increased intake of dry matter by up to $1.2 \mathrm{~kg}$ a day when supplementing the milking concentrate with bean.

The metabolism of dairy cows was evaluated on the basis of blood analysis (Table 5). At the beginning of the experiment, total protein concentration in serum slightly exceeded the reference range (60-80 $\mathrm{g} \cdot \mathrm{l}^{-1}$; Vrzgula et al. 1990) in all experimental groups. Significant differences were found between the control group and ME/MET groups. After one month of feeding the bean, total protein concentration decreased in ME group, but remained slightly increased in MET group (significant differences were found between MET and C; MET and ME). During other months of the study, increased total protein concentrations or significant differences among groups were not noted. These results indicate that increased protein concentrations in serum were not caused by the milking concentrates. During the study, urea concentration decreased in all groups from values slightly exceeding the reference range (physiological values: $3.0-5.0 \mathrm{mmol} \cdot \mathrm{l}^{-1}$; Vrzgula et al. 1990) to $4 \mathrm{mmol} \cdot \mathrm{l}^{-1}$ that can be considered as relatively low when taking actual milk production into account. Although there were certain differences among groups, no convincing tendency proving differences in utilization of nitrogenous substances were noted between experimental groups and the control group. In MI group, urea values tended to be higher as compared with ME and MET groups. Nevertheless, a significant difference was observed only at the end of the study 
Table 5. The characteristic of metabolism in dairy cows from control group $(\mathrm{C}, \mathrm{n}=8)$ and experimental groups (MI, $\mathrm{n}=8 ; \mathrm{ME}, \mathrm{n}=8 ;$ MET, $\mathrm{n}=8$ ) as measured during the study

\begin{tabular}{|c|c|c|c|c|c|}
\hline \multirow{2}{*}{ Indicator } & \multirow{2}{*}{ Group } & \multicolumn{4}{|c|}{ Weeks of the experiment } \\
\hline & & 0 & 4 & 8 & 12 \\
\hline \multirow{4}{*}{ Total protein $\left(\mathrm{g} \cdot \mathrm{l}^{-1}\right)$} & MI & $84.06 \pm 7.02$ & $83.24 \pm 6.90$ & $78.79 \pm 6.49$ & $79.73 \pm 6.92$ \\
\hline & $\mathrm{ME}$ & $84.93 \pm 4.61^{\mathrm{a}}$ & $79.76 \pm 4.46^{\mathrm{a}}$ & $76.58 \pm 3.03$ & $76.47 \pm 4.81$ \\
\hline & MET & $87.83 \pm 4.22^{b}$ & $86.48 \pm 5.96^{\mathrm{a}, \mathrm{b}}$ & $80.33 \pm 4.99$ & $77.29 \pm 4.08$ \\
\hline & $\mathrm{C}$ & $78.51 \pm 3.32^{\mathrm{a}, \mathrm{b}}$ & $78.34 \pm 4.59^{b}$ & $78.74 \pm 4.90$ & $77.65 \pm 7.17$ \\
\hline \multirow{4}{*}{ Urea $\left(\mathrm{mmol} \cdot \mathrm{l}^{-1}\right)$} & MI & $5.27 \pm 0.68$ & $5.20 \pm 1.12$ & $4.45 \pm 1.46$ & $3.96 \pm 0.66^{\mathrm{a}}$ \\
\hline & $\mathrm{ME}$ & $5.41 \pm 0.76$ & $4.83 \pm 0.52$ & $3.90 \pm 0.67$ & $3.31 \pm 0.29^{\mathrm{a}}$ \\
\hline & MET & $5.37 \pm 0.74$ & $4.44 \pm 0.93$ & $4.15 \pm 1.18$ & $3.38 \pm 0.73$ \\
\hline & $\mathrm{C}$ & $5.28 \pm 0.81$ & $4.95 \pm 0.88$ & $5.18 \pm 2.16$ & $3.61 \pm 0.29$ \\
\hline \multirow{4}{*}{ Cholesterol $\left(\mathrm{mmol} \cdot 1^{-1}\right)$} & MI & $4.52 \pm 0.98$ & $4.73 \pm 1.03$ & $4.39 \pm 0.96^{\mathrm{a}, \mathrm{b}}$ & $4,77 \pm 0,80^{\mathrm{a}, \mathrm{b}}$ \\
\hline & $\mathrm{ME}$ & $4.41 \pm 0.69$ & $5.33 \pm 0.99$ & $5.55 \pm 0.93^{\mathrm{a}, \mathrm{c}}$ & $6.18 \pm 0.96^{a, c}$ \\
\hline & MET & $4.35 \pm 1.99$ & $5.58 \pm 0.94$ & $5.41 \pm 0.73^{\mathrm{b}, \mathrm{d}}$ & $6.08 \pm 0.57^{\mathrm{b}, \mathrm{d}}$ \\
\hline & $\mathrm{C}$ & $4.64 \pm 1.28$ & $4.75 \pm 0.73$ & $4.47 \pm 0.39^{\mathrm{c}, \mathrm{d}}$ & $4.75 \pm 1.06^{\mathrm{c}, \mathrm{d}}$ \\
\hline \multirow{4}{*}{$\operatorname{NEFA}\left(\mathrm{mmol} \cdot \cdot^{-1}\right)$} & MI & $0.33 \pm 0.16$ & $0.24 \pm 0.06$ & $0.23 \pm 0.11$ & $0.26 \pm 0.17$ \\
\hline & $\mathrm{ME}$ & $0.30 \pm 0.13$ & $0.25 \pm 0.05$ & $0.19 \pm 0.03$ & $0.19 \pm 0.04$ \\
\hline & MET & $0.31 \pm 0.14$ & $0.35 \pm 0.17$ & $0.20 \pm 0.02$ & $0.21 \pm 0.02^{\mathrm{a}}$ \\
\hline & $\mathrm{C}$ & $0.27 \pm 0.16$ & $0.21 \pm 0.06$ & $0.36 \pm 0.41$ & $0.18 \pm 0.03^{\mathrm{a}}$ \\
\hline \multirow{4}{*}{$\mathrm{BHB}\left(\mathrm{mmol} \cdot \mathrm{l}^{-1}\right)$} & MI & $0.69 \pm 0.19$ & $0.77 \pm 0.19$ & $0.85 \pm 0.33$ & $0.77 \pm 0.29$ \\
\hline & $\mathrm{ME}$ & $0.65 \pm 0.25$ & $0.64 \pm 0.10$ & $0.69 \pm 0.25$ & $0.58 \pm 0.12^{\mathrm{a}}$ \\
\hline & MET & $0.73 \pm 0.24$ & $0.77 \pm 0.16$ & $0.85 \pm 0.15$ & $0.78 \pm 0.27$ \\
\hline & $\mathrm{C}$ & $0.72 \pm 0.14$ & $0.76 \pm 0.15$ & $0.79 \pm 0.21$ & $0.89 \pm 0.33^{\mathrm{a}}$ \\
\hline \multirow{4}{*}{ Bilirubin $\left(\mu \mathrm{mol} \cdot \cdot^{-1}\right)$} & MI & $5.61 \pm 1.20$ & $5.36 \pm 0.80$ & $4.64 \pm 1.17$ & $3.40 \pm 0.94$ \\
\hline & $\mathrm{ME}$ & $6.14 \pm 1.81$ & $5.64 \pm 1.28$ & $4.35 \pm 1.23$ & $3.45 \pm 0,60$ \\
\hline & MET & $5.96 \pm 0.55$ & $5.46 \pm 1.63$ & $3.99 \pm 1.11$ & $3.06 \pm 0.46$ \\
\hline & $\mathrm{C}$ & $5.60 \pm 0.36$ & $5.25 \pm 0.72$ & $4.64 \pm 3.31$ & $3.24 \pm 0.61$ \\
\hline \multirow{4}{*}{$\operatorname{GMT}\left(\mu \mathrm{kat} \cdot \mathrm{l}^{-1}\right)$} & MI & $0.51 \pm 0.29$ & $0.61 \pm 0.32$ & $0.60 \pm 0.20$ & $0.84 \pm 0.74$ \\
\hline & $\mathrm{ME}$ & $0.49 \pm 0.17$ & $0.81 \pm 0.35^{\mathrm{a}}$ & $0.87 \pm 0.42$ & $0.82 \pm 0.31$ \\
\hline & MET & $0.68 \pm 0.30$ & $0.76 \pm 0.33$ & $0.68 \pm 0.18$ & $0.71 \pm 0.20$ \\
\hline & $\mathrm{C}$ & $0.47 \pm 0.06$ & $0.51 \pm 0.10^{\mathrm{a}}$ & $0.55 \pm 0.08$ & $0.60 \pm 0.15$ \\
\hline
\end{tabular}

$p \leq 0.05$; the same letter in one column means significant difference between groups

between MI and ME groups. Technological treatment did not affect significantly the utilization of nitrogenous substances contained in the bean.

Furthermore, the effect of adding the bean to the diet on energy metabolism was studied. During the study, no significant energy deficit was observed in any experimental group. Average $\mathrm{BHB}$ concentrations were slightly above the physiological range $(\mathrm{BHB}<0.6$ mmol. ${ }^{-1}$; Kraft-Dürr 2001), and exceeded $0.8 \mathrm{mmol}^{-1} \mathrm{l}^{-1}$ only at the end of month 2 in MI and MET groups and at the end of the experiment in the control group. Significant differences among groups were observed only at the end of the experiment between groups $\mathrm{C}$ and ME. During the study, no significant increase of body fat mobilization was revealed in dairy cows. NEFA concentration was in all groups within the reference range of $0.1-0.35$ $\mathrm{mmol} \cdot \mathrm{l}^{-1}$ (Vrzgula et al. 1990). Although there were certain differences between groups during the study, no convincing tendency proving specific effect of the milking concentrate was revealed. Interesting results were found for cholesterol. Serum concentration of cholesterol increased in groups ME and MET during the experiment (physiological range 2.6-5.2 mmol· $\cdot \mathrm{l}^{-1}$, Vrzgula et al. 1990). At the end of the second and third month of the study, cholesterol concentration in groups fed Merkur was significantly higher than in 
Mistral group and control group. Cholesterol concentration in blood serum depends on the synthetic function of liver and the content of fat in the diet (Pechová et al. 2006). Although the concentration of fat in the milking concentrate was lower compared to the control group, it was almost identical in all experimental groups. The difference between cultivars in serum cholesterol concentration is therefore difficult to explain.

Although energy metabolism of dairy cows was not seriously impaired, all experimental animals (including those from the control group) showed significant alteration of liver that was manifested by higher activity of GMT in blood serum (reference values $0.2-0.5$ $\mu \mathrm{kat} \cdot \mathrm{l}^{-1}$,Vrzgula et al. 1990). During the study, increased GMT activity was observed in all groups, indicating damage to liver parenchyma. At the beginning of the experiment, the highest average GMT activity values were found in MET group. Later on, however, MET dairy cows showed the least increase of GMT activities among all groups. At the end of the first month, the highest GMT activity values were noted in ME group. The only significant difference was observed between groups $\mathrm{ME}$ and $\mathrm{C}$ at the end of the first month. As GMT values were high in all groups from the very beginning of the experiment, they were probably not directly connected with the experimental diet. They were rather increased due to a negative effect of other components of the diet (worse-quality silage). At the beginning and at the end of the first month of the experiment, bilirubin values were slightly above the physiological range of $0.17-5.13 \mu \mathrm{mol} \cdot{ }^{-1}$ (Vrzgula et al. 1990) in all groups. Later on they decreased. Increased bilirubin values were caused by high pressure exerted on liver in early lactation. With gradual stabilization of dairy cows' metabolism, serum concentration of bilirubin was decreasing in all groups. The presented results did not indicate that antinutritional substances in the bean influenced negatively liver parenchyma.

Mineral metabolism was not significantly impaired by adding the bean to milking concentrates either. Although the treated bean contains more calcium, this was not reflected by increased calcium concentration in blood (physiological values 2.25-3.0 $\mathrm{mmol} \cdot \mathrm{l}^{-1}$, Vrzgula et al. 1990). After the third sampling, a significant difference in calcium values was identified between MET $\left(2.30 \pm 0.11 \mathrm{mmol} \cdot \mathrm{l}^{-1}\right)$ and $\mathrm{C}\left(2.14 \pm 0.15 \mathrm{mmol} \cdot \mathrm{l}^{-1}\right)$ groups. This sampling also revealed significantly lower magnesium values in MET group $(0.88$ $\left.\pm 0.06 \mathrm{mmol} \cdot \mathrm{l}^{-1}\right)$ as compared to MI $\left(0.98 \pm 0.09 \mathrm{mmol}^{-1} \mathrm{l}^{-1}\right)$ and ME groups $(1.00 \pm 0.09$ mmol $\cdot 1^{-1}$ ) (physiological values $0.8-1.07 \mathrm{mmol} \cdot \mathrm{l}^{-1}$, Vrzgula et al. 1990). However, as this result was observed only in one sampling, it cannot be confirmed that decreased availability of $\mathrm{Mg}$ in the organism was affected by bean treatment. In general, blood concentration of calcium, phosphorus and magnesium, as measured during the study, complied with reference values. Homeostasis was not impaired in any group.

Results of ruminal fluid analysis are shown in Table 6. During the study, no animal showed any significant disturbances of ruminal digestion; $\mathrm{pH}$ levels of ruminal fluid were always in physiological range (6.2-7.0; Vrzgula et al. 1990). However, during the last sampling, a significant difference was noted between groups $\mathrm{MI}$ and $\mathrm{C}$. Lower $\mathrm{pH}$ values could be associated with a lower content of fibre in the diet. Total acidity (TA) values in all groups were always at the upper limit of the physiological range of 12-24 titre $\mathrm{u}$. (Vrzgula et al. 1990). A significant difference in TA values was identified at the beginning of the experiment between groups MET and C. Concentration of volatile fatty acids corresponded with a good rate of ruminal digestion. It fluctuated during the study, but no univocal increasing or decreasing tendency associated with adding the bean to the milking concentrate or with bean treatment was observed (physiological values $80-120 \mathrm{mmol} \cdot \mathrm{l}^{-1}$, Vrzgula et al. 1990). Similar to Bartsch and Valentine (1986), no significant effect of the bean diet was observed on VFA production. Infusoria counts were relatively high in all groups (reference values: $300-500.10^{9} \cdot 1^{-1}$; Vrzgula et al. 1990), significant differences among groups were noted at the end of the study only: significantly higher values were observed in MET group against ME group and in MI group against the control group. 
Table 6 . The characteristic of ruminal fermentation in dairy cows from control group $(\mathrm{C}, \mathrm{n}=8)$ and experimental groups (MI, $\mathrm{n}=8 ; \mathrm{ME}, \mathrm{n}=8 ; \mathrm{MET}, \mathrm{n}=8$ ) as measured during the study

\begin{tabular}{|c|c|c|c|c|c|}
\hline \multirow{2}{*}{ Indicator } & \multirow{2}{*}{ Group } & \multicolumn{4}{|c|}{ Weeks of the experiment } \\
\hline & & 0 & 4 & 8 & 12 \\
\hline \multirow{4}{*}{$\mathrm{pH}$} & MI & $6.56 \pm 0.31$ & $6.43 \pm 0.25$ & $6.21 \pm 0.42$ & $6.47 \pm 0.25^{\mathrm{a}}$ \\
\hline & $\mathrm{ME}$ & $6.24 \pm 0.30$ & $6.39 \pm 0.19$ & $6.27 \pm 0.25$ & $6.23 \pm 0.30$ \\
\hline & MET & $6.24 \pm 0.30$ & $6.38 \pm 0.20$ & $6.25 \pm 0.22$ & $6.21 \pm 0.32$ \\
\hline & $\mathrm{C}$ & $6.49 \pm 0.17$ & $6.54 \pm 0.21$ & $6.41 \pm 0.32$ & $6.18 \pm 0.20^{\mathrm{a}}$ \\
\hline \multirow{4}{*}{ Total acidity (titre.u.) } & MI & $21.81 \pm 5.73$ & $23.76 \pm 3.88$ & $29.13 \pm 11.63$ & $20.74 \pm 4.41^{\mathrm{a}}$ \\
\hline & $\mathrm{ME}$ & $28.38 \pm 8.62$ & $23.90 \pm 3.21$ & $26.13 \pm 6.60$ & $25.54 \pm 6.43$ \\
\hline & MET & $28.46 \pm 8.48^{\mathrm{a}}$ & $24.00 \pm 4.36$ & $25.24 \pm 6.09$ & $25.99 \pm 7.42$ \\
\hline & $\mathrm{C}$ & $21.11 \pm 3.67^{\mathrm{a}}$ & $22.79 \pm 4.84$ & $26.13 \pm 6.74$ & $26.23 \pm 4.88^{\mathrm{a}}$ \\
\hline \multirow{4}{*}{$\begin{array}{l}\text { Count of infusoria } \\
\qquad\left(.10^{3} \cdot \mathrm{ml}^{-1}\right)\end{array}$} & MI & $312 \pm 59^{\mathrm{a}}$ & $398 \pm 185$ & $585 \pm 266$ & $638 \pm 285^{a, b}$ \\
\hline & $\mathrm{ME}$ & $442 \pm 231$ & $352 \pm 178$ & $496 \pm 292$ & $323 \pm 121^{b, c}$ \\
\hline & MET & $316 \pm 148$ & $324 \pm 156$ & $542 \pm 340$ & $572 \pm 233^{\mathrm{c}}$ \\
\hline & $\mathrm{C}$ & $459 \pm 138^{\mathrm{a}}$ & $394 \pm 97$ & $463 \pm 76$ & $394 \pm 101^{a}$ \\
\hline \multirow{4}{*}{$\operatorname{VFA}\left(\mathrm{mmol} \cdot 1^{-1}\right)$} & MI & $94.9 \pm 22.1^{\mathrm{a}, \mathrm{b}}$ & $105.0 \pm 8.8^{\mathrm{a}, \mathrm{b}}$ & $130.7 \pm 20.8$ & $113.6 \pm 16.5$ \\
\hline & $\mathrm{ME}$ & $122.4 \pm 15.6^{\mathrm{a}}$ & $114.3 \pm 11.8$ & $120.2 \pm 14.9$ & $116.4 \pm 7.0^{\mathrm{a}}$ \\
\hline & MET & $123.6 \pm 14.3^{\mathrm{c}, \mathrm{b}}$ & $115.9 \pm 9.4^{b}$ & $119.9 \pm 12.6$ & $124.5 \pm 17.2$ \\
\hline & $\mathrm{C}$ & $107.2 \pm 11.8^{\mathrm{c}}$ & $119.9 \pm 10.9^{\mathrm{a}}$ & $116.8 \pm 21.7$ & $129.6 \pm 13.8^{\mathrm{a}}$ \\
\hline \multirow{4}{*}{ Acetic acid (mol\%) } & MI & $58.63 \pm 3.61$ & $57.94 \pm 2.59$ & $58.40 \pm 3.88$ & $61.93 \pm 3.60$ \\
\hline & $\mathrm{ME}$ & $58.91 \pm 3.68$ & $57.00 \pm 4.72$ & $57.64 \pm 2.77$ & $58.11 \pm 3.20$ \\
\hline & MET & $59.55 \pm 4.59$ & $59.09 \pm 3.32$ & $59.21 \pm 2.84$ & $61.14 \pm 3.76$ \\
\hline & $\mathrm{C}$ & $60.00 \pm 2.30$ & $57.26 \pm 2.95$ & $60.10 \pm 2.76$ & $59.94 \pm 4.40$ \\
\hline \multirow{4}{*}{ Propionic acid (mol\%) } & MI & $21.63 \pm 3.29$ & $20.64 \pm 2.93^{\mathrm{a}}$ & $22.11 \pm 4.73$ & $16.70 \pm 3.27^{\mathrm{a}}$ \\
\hline & $\mathrm{ME}$ & $22.75 \pm 5.01$ & $24.13 \pm 3.17^{\mathrm{a}}$ & $23.21 \pm 3.68^{\mathrm{a}}$ & $21.76 \pm 3.58^{\mathrm{a}, \mathrm{b}, \mathrm{c}}$ \\
\hline & MET & $22.24 \pm 5.66$ & $22.13 \pm 3.65$ & $19.55 \pm 3.66$ & $17.75 \pm 3.15^{\mathrm{b}}$ \\
\hline & $\mathrm{C}$ & $20.08 \pm 1.57$ & $21.93 \pm 2.70$ & $19.18 \pm 2.18^{\mathrm{a}}$ & $17.85 \pm 2.96^{\circ}$ \\
\hline \multirow{4}{*}{$\mathrm{NH}_{3}\left(\mathrm{mmol}^{-1} \mathrm{l}^{-1}\right)$} & $\mathrm{MI}$ & $5.87 \pm 2.55^{\mathrm{a}}$ & $5.21 \pm 2.55^{\mathrm{a}}$ & $4.88 \pm 2.49$ & $3.08 \pm 0.89$ \\
\hline & $\mathrm{ME}$ & $4.28 \pm 1.24$ & $1.81 \pm 0.92^{\mathrm{a}}$ & $2.68 \pm 1.90$ & $3.90 \pm 1.66$ \\
\hline & MET & $3.22 \pm 1.54^{\mathrm{a}}$ & $2.96 \pm 2.25$ & $2.77 \pm .1 .25$ & $3.65 \pm 1.89$ \\
\hline & $\mathrm{C}$ & $5.85 \pm 3.16$ & $3.42 \pm 1.89$ & $5.79 \pm 5.13$ & $3.37 \pm 2.60$ \\
\hline \multirow{4}{*}{ Lactic $\operatorname{acid}\left(\mathrm{mmol} \cdot 1^{-1}\right)$} & MI & $0.17 \pm 0.05$ & $0.28 \pm 0.07$ & $0.31 \pm 0.06^{\mathrm{a}}$ & $0.35 \pm 0.07^{\mathrm{a}}$ \\
\hline & $\mathrm{ME}$ & $0.30 \pm 0.23$ & $0.27 \pm 0.14$ & $0.43 \pm 0.28$ & $1.64 \pm 1.29^{\mathrm{a}, \mathrm{b}}$ \\
\hline & MET & $0.13 \pm 0.03$ & $0.26 \pm 0.09$ & $0.37 \pm 0.04^{\mathrm{a}}$ & $0.42 \pm 0.16^{b}$ \\
\hline & $\mathrm{C}$ & $0.20 \pm 0.16$ & $0.30 \pm 0.12$ & $0.42 \pm 0.16$ & $1.60 \pm 2.11$ \\
\hline
\end{tabular}

$p \leq 0.05$; the same letter in one column means significant difference between groups

As infusoria counts corresponded with reference values during the study, a negative effect of the bean diet on infusoria count can be ruled out. Ammonia values in ruminal fluid were relatively low in all groups including the control group (fed soybean characterized by low degradability of nitrogenous substances). Save for minor exceptions, ammonia levels did not even reach the lower limit of the physiological range of 4-12 $\mathrm{mmol}^{-1} \mathrm{l}^{-1}$ (Vrzgula et al. 1990). Significant differences were noted after the first month of the experiment between groups MI and ME. Later on, the values evened out. Low ammonia values point to a lower content of degradable nitrogenous substances in a diet. Adding $20 \%$ of the bean to the diet did not significantly affect the production of ammonia in the rumen.

As far as VFA distribution is concerned, higher amounts of propionic acid in ME group in all samplings should be noted. At the end of the experiment, differences between this group and all other groups were significant. In most cases, the increase of propionic acid content was to the exclusion of levels of n-butyric acid whose distribution, as measured 
during the study, was the least. This shift towards a higher production of propionic acid can be viewed as positive. The analysis of individual production mixtures revealed no differences that could explain varying distribution of individual VFAs. A higher production of propionic acid was probably caused by increased degradability of starch contained in the Merkur cultivar. Reduced degradability of starch due to the treatment of this cultivar corresponded with the results of other studies (Goelema et al. 1998).

Evaluation of milk production

In the course of 90-day lactation, the daily milk yield in all groups showed similar decreasing tendencies. No significant differences were found between groups (Table 7). The evaluation of milk yield reduction index (milk yield before the beginning of the study was considered as $100 \%$ ) between individual groups revealed no significant differences. Table 7 shows that at the beginning of the study milk yield decreased considerably to $93.2 \%$ in MI group and to $91.6 \%$ in ME group. However, these values evened out in the following months. The drop in milk yield at the beginning of the experiment could be caused by adaptation of dairy cows to the changed diet. At the end of the study, the most significant milk yield decrease was noted in MET and $\mathrm{C}$ groups, but the differences between groups were not significant. We found no significant effect of adding the bean to the feeding mixture on milk production and individual milk components. Fat and protein concentration in milk slightly fluctuated. At the beginning of the experiment, higher fat concentration in milk was noted in MI and MET groups compared to ME and C groups. However, these differences evened out in the following months. Compared to other groups, MI group showed a lower concentration of protein at the beginning of the experiment. Nevertheless, the differences were not significant. It is believed that this was not influenced by the milking concentrate, as the differences leveled off in the following months.

Table 7: Milk production in individual groups (MI - Mistral, $\mathrm{n}=8 ; \mathrm{ME}-$ Merkur, $\mathrm{n}=8$; MET - Merkur-treated, $\mathrm{n}=8 ; \mathrm{C}-$ control, $\mathrm{n}=8$ ) during the study

\begin{tabular}{|c|c|c|c|c|c|}
\hline \multirow{3}{*}{ Indicator } & \multirow{2}{*}{ Group } & \multicolumn{4}{|c|}{ Months of the experiment } \\
\cline { 2 - 6 } & & 0 & 1 & 2 & 3 \\
\hline \multirow{4}{*}{ Daily milk yield (1) } & MI & $30.88 \pm 3.72$ & $28.88 \pm 6.51$ & $27.13 \pm 8.16$ & $26.63 \pm 4.47$ \\
\cline { 2 - 6 } & ME & $30.00 \pm 4.24$ & $27.50 \pm 4.47$ & $26.13 \pm 2.62$ & $25.38 \pm 3.31$ \\
\cline { 2 - 6 } & MET & $30.50 \pm 3.84$ & $29.38 \pm 3.90$ & $26.88 \pm 4.28$ & $24.25 \pm 4.49$ \\
\cline { 2 - 6 } & $\mathrm{C}$ & $31.63 \pm 3.71$ & $31.0 \pm 3.00$ & $28.50 \pm 4.74$ & $25.63 \pm 5.29$ \\
\hline \multirow{4}{*}{ Milk yield index (\%) } & MI & 100 & $93.21 \pm 17.28$ & $87.51 \pm 25.11$ & $86.23 \pm 9.65$ \\
\cline { 2 - 6 } & ME & 100 & $91.62 \pm 8.44$ & $88.22 \pm 11.16$ & $84.93 \pm 7.50$ \\
\cline { 2 - 6 } & MET & 100 & $96.60 \pm 7.22$ & $88.39 \pm 10.05$ & $80.02 \pm 14.56$ \\
\cline { 2 - 6 } & $\mathrm{C}$ & 100 & $99.84 \pm 7.81$ & $91.93 \pm 13.23$ & $80.00 \pm 11.60$ \\
\hline & $\mathrm{MI}$ & $3.85 \pm 0.34$ & $3.73 \pm 0.36$ & $3.47 \pm 0.22$ & $3.84 \pm 0.56$ \\
\cline { 2 - 6 } & $\mathrm{ME}$ & $3.51 \pm 0.41$ & $3.43 \pm 0.45$ & $3.65 \pm 0.44$ & $4.09 \pm 0.65$ \\
\cline { 2 - 6 } & $\mathrm{MET}$ & $3.72 \pm 0.73$ & $3.60 \pm 0.67$ & $3.69 \pm 0.75$ & $3.87 \pm 0.70$ \\
\cline { 2 - 6 } & $\mathrm{C}$ & $3.65 \pm 0.33$ & $3.54 \pm 0.25$ & $3.53 \pm 0.28$ & $3.90 \pm 0.42$ \\
\cline { 2 - 6 } & $\mathrm{MI}$ & $3.06 \pm 0.20$ & $3.12 \pm 0.24$ & $3.33 \pm 0.24$ & $3.60 \pm 0.43$ \\
\cline { 2 - 6 } & $\mathrm{ME}$ & $3.27 \pm 0.15$ & $3.24 \pm 0.14$ & $3.35 \pm 0.22$ & $3.62 \pm 0.37$ \\
\cline { 2 - 6 } & $\mathrm{MET}$ & $3.18 \pm 0.18$ & $3.13 \pm 0.12$ & $3.49 \pm 0.41$ & $3.80 \pm 0.29$ \\
\cline { 2 - 6 } & $\mathrm{C}$ & $3.22 \pm 0.14$ & $3.26 \pm 0.13$ & $3.34 \pm 0.20$ & $3.41 \pm 0,51$ \\
\hline \multirow{4}{*}{ Lactose (\%) } & $\mathrm{MI}$ & $5.04 \pm 0.20$ & $5.01 \pm 0.22$ & $5.01 \pm 0.20$ & $5.06 \pm 0.16$ \\
\cline { 2 - 6 } & $\mathrm{ME}$ & $5.13 \pm 0.15$ & $5.11 \pm 0.10$ & $5.00 \pm 0.21$ & $4.97 \pm 0.31$ \\
\cline { 2 - 6 } & $\mathrm{MET}$ & $4.92 \pm 0.42$ & $5.09 \pm 0.06$ & $5.13 \pm 0.07$ & $5.05 \pm 0.10$ \\
\cline { 2 - 6 } & $\mathrm{C}$ & $5.15 \pm 0.07$ & $5.11 \pm 0.11$ & $5.09 \pm 0.08$ & $4.92 \pm 0.23$ \\
\hline
\end{tabular}

$p \leq 0.05$; the same letter in one column means significant difference between groups 
Results of trials investigating the effect of diets containing bean on milk production vary. Brunschwig and Lamy (2003) studied the utilization of pulses with higher protein content in dairy cows. In contrast to the results of the current study, they observed increased milk yield and different protein and fat content in milk after feeding the bean vs. soybean. Similar results were found by Bartsch and Valentine (1986) who reported increased milk production in cows at the beginning of the lactation period fed pulses (bean meal) compared to grain diet. Abeni et al. (1999) observed lower milk performance in dairy cows fed ground bean supplements and a higher fat content in milk. The content of milk protein was not affected by adding the bean to milking concentrates. Cros et al. (1992) reported increased concentrations of essential amino acids (lysine, valine, phenylalanine and tyrosine) in the milk of dairy cows fed extruded beans ( $80 \%$ vs. $51 \%$ in untreated beans). Feeding by-products of bean treatment (max. 30\% of concentrate mixture) resulted in increased milk performance and changed milk composition. Furthermore, feeding costs were lower compared to commercial concentrates (Al-Saiady 1998). The studies indicate that the horsebean is a useful source of starch and protein for dairy cows and has no negative effect on milk composition.

On the basis of the current study, the bean can be used in $20 \%$ in the milking concentrate of dairy cattle instead of soybean. Health risks associated with anti-nutritional content of native beans are non-significant for high-producing dairy cows. The technological treatment of the bean cultivar with a high content of anti-nutritional substances is not necessary.

\section{Užitkovost a metabolismus dojnic při zkrmování bobu (Vicia faba) s různým obsahem antinutričních látek}

Cílem pokusu bylo zhodnotit možnost nahrazení sóji v krmné dávce dojnic bobem s různým obsahem antinutričních látek na zdravotní stav a užitkovost dojnic. Pokus trval 12 týdnů, bylo sledováno 32 dojnic (od 3. do 6. týdne po porodu), které byly rozděleny do 4 skupin. Krmné dávky byly vybilancovány na obsah NL a energie. Dojnice pokusných skupin (MI, ME, MEU) dostávaly produkční směs s $20 \%$ podílem bobu (MI - odrůda MISTRAL s nízkým obsahem antinutričních látek; ME - odrůda MERKUR s vysokým obsahem antinutričních látek; MET - odrůda MERKUR po technologické úpravě snižující obsah antinutričních látek). Na základě klinického hodnocení zdravotního stavu dojnic a sledováním příjmu krmiva nebyl zjištěn negativní vliv pokusných směsí. Rovněž nedošlo k narušení energetického, dusíkového ani minerálního metabolismu. Z hlediska ovlivnění užitkovosti dojnic nebyly mezi skupinami zjištěny signifikantní rozdíly (nádoj, produkce bílkoviny a laktózy). Na základě realizovaného pokusu je možno doporučit zkrmování bobu v množství $20 \%$ produkční krmné směsi jako vhodného zdroje bílkovin i energie pro dojnice. Ve výživě vysokoprodukčních dojnic nebyla prokázána významná zdravotní rizika související s obsahem antinutričních látek v nativním bobu.

\section{Acknowledgement}

This work was supported by the Grant Agency of the Ministry of Agriculture (Grant No. QF 3070).

\section{References}

Abeni F, Bergoglio G, Masoero G, Piva G, Bertoni G, Masoero F, Bani P, Calamari L 1999: Faba bean seed in red pied Valdostana feeding. Proceedings of the A.S.P.A. XIII Congress, June 21 - 24. Piacenza, Italy, pp. 410-412

Al-Saiady MY 1998: Utilization of faba bean (Vicia faba) by-products as feed ingredients for lactating cows. Asian Austral J Anim 11: 255-259

Aleksić D, Grubić G, Pavličević A 1999a: Protein degradability of some concentrate feeds used in dairy cow nutrition. Acta Vet-Beogr 49: 263-268

Aleksić D, Grubić G, Pavličević A 1999b: Starch degradability of some concentrate feeds used in dairy cow nutrition. Acta Vet-Beogr 49: 269-274 
Aguilera JF, Bustos M, Molina E 1992: The degradability of legume seed meals in the rumen: effect of heat treatment. Anim Feed Sci Technol 36: 101-112

Bartsch BD, Valentine SC 1986: Grain legumes in dairy cow nutrition. Proc Aust Soc Anim Prod 16: 32-34

Benchaar C, Vernay M, Bayourthe C, Moncoulon R 1992: Incidence of bean (Vicia faba) extrusion on starch and nitrogen intestinal flows in lactating cows. Reprod Nutr Dev 32: 265-275

Broderick GA, Kang JH 1980: Automated simultaneous determination of ammonia and total amino acids in ruminal fluid and in vitro media. Am Dairy Sci Assoc 63:64-75

Brunschwig P, Lamy JM 2003: High-protein crops contribute to the feed self-sufficiency of dairy herds without any adverse effect on the performances (Les protéagineux contribuent à l'autonomie alimentaire du troupeau laitier alimenté avec du maïs ensilage, sans pénaliser les performances). Fourrages 175: 395-402

Cerioli C, Fiorentini L, Prandini A, Piva G 1998: Antinutritional factors and nutritive value of different cultivars of pea, chickpea and faba bean. In: Recent advances of research in antinutritional factors in legume seeds and rapeseed. Wageningen Pers, Wageningen (Netherlands). EAAP Publ 93: 43-46

Cros P, Vernay M, Moncoulon R 1991: In situ evaluation of the ruminal and intestinal degradability of extruded whole horsebeans. Reprod Nutr Dev 31: 249-255

Cros P, Vernay M, Bayourthe C, MoncoulON R 1992: Influence of extrusion on ruminal and intestinal disappearance of amino acids horsebean. Can J Anim Sci 72: 89-96

Dvořák R, Pechová A, Pavlata L, Klejdus B, Kovařčík K, Dostálová J, Culková J, Filípek J, Švajdlenka E, Čapková V 2006: Reduction in the content of antinutritional substances in faba beans (Vicia faba) by different treatments. Slov Vet Res 43 (Suppl.): 174-179

Goelema JO, Spreeuwenberg MAM, Hof G, Van der Poel AFB, Tamminga S 1998: Effect of pressure toasting on the rumen degradability and intestinal digestibility of whole and broken peas, lupins and faba beans and a mixture of these feedstuffs. Anim Feed Sci Technol 76: 35-50

Kraft W, Dürr UM 2001: Clinical laboratory diagnostics in veterinary medicine (In Czech). Hajko and Hajková, Bratislava, $365 \mathrm{p}$.

Martinez TF, Moyano FJ, Diaz M, Barroso FG, Alarcon FJ 2004: Ruminal degradation of tannin-treated legume meals. J Sci Food Agric 84: 1979-1987

Pechová A, Dvořák R, Drastich P, Lubojacká V, Pavlata L, Poul J 2006: Influence of increased lipid content in diet in the form of treated rapeseed meal on the metabolism and milk yield of dairy cows in the first third of lactation. Vet Med-Czech 51: 346-355

Vrzgula L, Alijev AA, Barej W, Bartko P, Bouda J, Dvořák R, Garbašanski P, Illek J, Jagoš P, Karsai F, Kóňa E, Kováč G, Nedkova L, Sokol J, Sova Z, Schäfer M 1990: Metabolic disorders and their prevention in farm animals (In Slovak). Bratislava, Príroda, 503 p.

Yu P, Goelema JO, Tamminga SC 2000: Determination of optimal conditions of pressure toasting on horse beans for dairy feed industry, by the DVE/OEB model. Anim Feed Sci Technol 86: 165-176 